\title{
Rice wheat cropping system in Nepal: Issues
} concerning sustainability

\author{
Suraj Lamsal ${ }^{1 *}$, Rabin Khadka²
}

${ }^{1}$ Naini Agricultural Institute, Sam Higginbottom University of Agricultural, Technology and Sciences, Prayagraj-211007, U.P,India

${ }^{2}$ Department of Agronomy, Agriculture and Forestry University, Rampur, Nepal

Email: 1amsalsuraj199@gmail.com

\begin{abstract}
Rice wheat cropping system has been widely adopted in Nepal since very long, but much less been studied about the sustainability aspects of this practice. South Asian countries-, as well as other rice-growing countries, have already experienced different ecological and environmental impacts of the long-term rice-wheat system. Also,climate change seems to inflict the rice-based farming system to a varied extent depending uponagroecological regions. In the meantime, the growth in yield of rice is plateauing to less than $1.5 \%$ although productivity is well below other South Asian countries. With the heightening consumption of agrochemicals and its subsequent impact on air, water and soil have to be taken into consideration. Rice-wheat system being heavy consumer of nutrient and waterraises question about the sustainable consumption of resources. The increasing dominance of hybrid varieties posses' threat of extinction of local landraces of rice. Apart from environmental and agronomic issues it also maybe affected by socio-economic issues of Nepalese farming families. Extensive studies are yet to be done, but practices like conservation agriculture and sustainable intensification practices are found to make system more resilient. The aim of this review is to discuss such issues associated with sustainability and propose some probable sustainability measures.
\end{abstract}

Keywords-agrochemicals, climate change, sustainable, conservation agriculture.

\section{INTRODUCTION}

The farming system in Nepal is rice-based, and rice-wheat cropping system (RWCS) is the most practised system in the country. RWCS covers about 0.5 million ha of land in the country and has share of $65.8 \%$ and $72.1 \%$ of total area and total production of cereal crops in the country (Khanal et al., 2012). It covers about $37 \%$ of rice growing area and $85 \%$ of wheat growing area in the country (Tripathi et al., 2010). Rice alone contributes to $20 \%$ of agricultural GDP of country and $53 \%$ of total cereal production in Nepal including onethird of total calorie intake of Nepalese population (Tripathi et al., 2019). With the availability of hybrid and high yielding varieties all-round the country, this system is gaining more popularity.

Even though farmers prefer this cropping pattern across South Asia, these two crops have significant differences in field preparation techniques and water management system. Rice is normally grown in water stagnated field whereas following crop wheat requires well-drained soil condition. Under this system, Nepalese farmers cultivate paddy as a summer crop and planted during June/July whereas wheat is grown as a winter crop and planted in November following the harvest of paddy. However, there is wide variation in planting and harvesting time of both crops depending upon agroclimatic condition, irrigation facilities, cropping pattern and type of variety cultivated. Even thoughthe rice-wheat system is unavoidable cropping pattern for food security of Asia, there have been evidence of sustainability concerns associated with diverse expressions of the system. India and China have already experienced impingements of long-term intensive rice-wheat system on biotic as well as abiotic components of environment. Nepal too cannot be relieved from impediments of intensive RWCS regarding sustainability if we do not correct our steps. Though there exists variation in issues concerning sustainability of ricewheat system across different rice-growing countries of Asia ultimately, they all are colligated with food security of whole world. There has not been significant research on sustainability aspects of RWCS in Nepal. This paper aims to identify the sustainability issues that are directly or indirectly associated with long-term intensive rice-wheat system and suggest some relevant amelioration practices for Nepal. 


\section{SUSTAINABILITY CONCERNS}

\subsection{Impacts of Climate Change in Nepalese RWCS}

Climate change is one of the most critical factors in the sustainability of the entire agriculture and farming system of today's world. Rice and wheat, both being highly critical with temperature and precipitation pattern, are affected to a significant degree by climate change. Nepal though it lies in tropical region, covers wide range of agroclimatic zones varying with altitudinal gradient. Nepalese agriculture is mostly rainfed, and big fraction of farmers practice subsistence farming. The irrigated portion of rice cultivable land in Nepal is only $56 \%$, and rest is rainfed of which $39 \%$ is rainfed lowland and 5\% is rainfed uplands (Tripathi et al., 2019). The reliability of irrigation water is poor even for irrigated area.

It is projected that Nepal's mean annual temperature will increase by an average of $1.2{ }^{\circ} \mathrm{C}$ by $2030,1.7^{\circ} \mathrm{C}$ by 2050 and $3^{\circ} \mathrm{C}$ by the end of this century (Adhikari et al., 2017). The rise in temperature is closely associated with other issues like soil moisture deficit, the outbreak of diseases and insect-pest, incidence of new pests, diverse weed flora and virulence of pathogens (Bhatt et al., 2015). The threshold daytime maximum temperature for rice is $29.9^{\circ} \mathrm{C}$ in Terai. Since the maximum temperature in Terai is already high above the threshold, productivity is likely to decline (Adhikari et al., 2017). It was found that for every $1{ }^{\circ} \mathrm{C}$ rises in average minimum temperature during September and January results decline in rice yield by $365 \mathrm{~kg} / \mathrm{ha}$ and $38 \mathrm{~kg} / \mathrm{ha}$ respectively (Pant, 2013). It was found that impact of the rise in minimum temperature is higher compared to rise in monthly maximum temperature. A study done by (Adhikari et al., 2017) showed that aberration in maximum temperature over the study period of 1990 to $2013 \mathrm{had}$ negative consequences in rice yield in both hilly and Terai region of Nepal. Unprecedented rainfall during the harvesting period of both rice and wheat is another issue Nepalese farmer are facing in recent years. Drought is another impediment for agriculture in Nepal. 0.52 million ha of the area is affected by drought in Nepal (Tripathi et al., 2019).

The spatial and temporal variation in precipitation pattern negatively impacts the rice-wheat cropping since $65 \%$ of cultivation is rainfed (Gahatraj et al., 2018). The conventional method of rice cultivation requires about 1500 $\mathrm{mm}$ of water after transplanting to complete its life cycle before which seedling raising and puddling requires $50 \mathrm{~mm}$ of water (Karkaliya et al., 2018). Studies have shown that average annual rainfall decreased at a rate of $10.21 \mathrm{~mm} / \mathrm{year}$ and mean temperature increased at rate of $0.02^{\circ} \mathrm{C} /$ year between 1984 and 2014 in central part of southern Terai (Dhakal et al., 2016). Terai region of Nepal has already experienced adverse impact of climate change on rice production. Temperature level has already crossed threshold level, and the growth rate of paddy production has been limited to $1.4 \%$ per year for past two decades (Adhikari et al., 2017). Crop production nationwide was reduced by $12.5 \%$ in the year 2005 and 2006 due to early monsoon whereas winter drought of 2009 reduced wheat production by $14.5 \%$ (Dhakal et al., 2016). The minimum optimum threshold temperature for wheat production in Nepal is $20^{\circ} \mathrm{C}$, and annual increase of temperature in Nepal is $0.06^{\circ} \mathrm{C}$ (Bhujel et al., 2014). Studies done by (Parajuli and Devkota, 2016) at Bhairahawa showed that wheat production might increase with rising temperature to certain extent since annual average maximum temperature at area of wheat cultivation was $18.3^{\circ} \mathrm{C}$. Extinction of indigenous varieties of rice such as aromatic rice varieties, stress-tolerant varieties etc. is new threat climate change possess in recent time.

\subsection{Stagnation in Yield}

The history of yield trend of rice and wheat doesn't seem to be so ameliorating in Nepal. Rice yield in Nepal was highest among south Asian countries in 1960s, but it is lowest in recent years (Tripathi et al., 2019). The overall growth rate of rice yield was only $0.5 \%$ between 1958 and 1997 whereas wheat yield grew at a rate of $0.8 \%$ per annum between 1962 to 1998(Katkai et al., 2001). Study done by Ladha et al., (2001) for 20 years at Parwanipur, Nepal showed that even with full recommended dose of NPK and FYM, yield for rice and wheat were $<3.15$ tons/ha and $<2.16$ tons/ha respectively which were only $40-50 \%$ of potential attainable yields. Another long-term study was done by Regmi et al., (2002) at Regional Agriculture Research Station, Bhairahawa, Nepal showed net loss of 62.3 and $15.2 \mathrm{~kg} / \mathrm{ha} /$ year of potassium(K) in NPK and FYM treatments respectively at the end of 20 years. However, productivity of rice and wheat were increasing at rate of $1.65 \%$ and $2.52 \%$ between 1995 to 2014 (Gairhe et al., 2018). But still productivity of rice and wheat were only $3.36 \mathrm{t} / \mathrm{ha}$ and $2.59 \mathrm{t} / \mathrm{ha}$ respectively in 2014 (Gairhe et al., 2018) which is fairly below when compared with other South Asian countries. 


\section{Yield Trend of Rice and Wheat During 2007/08-2016/17 in Nepal}

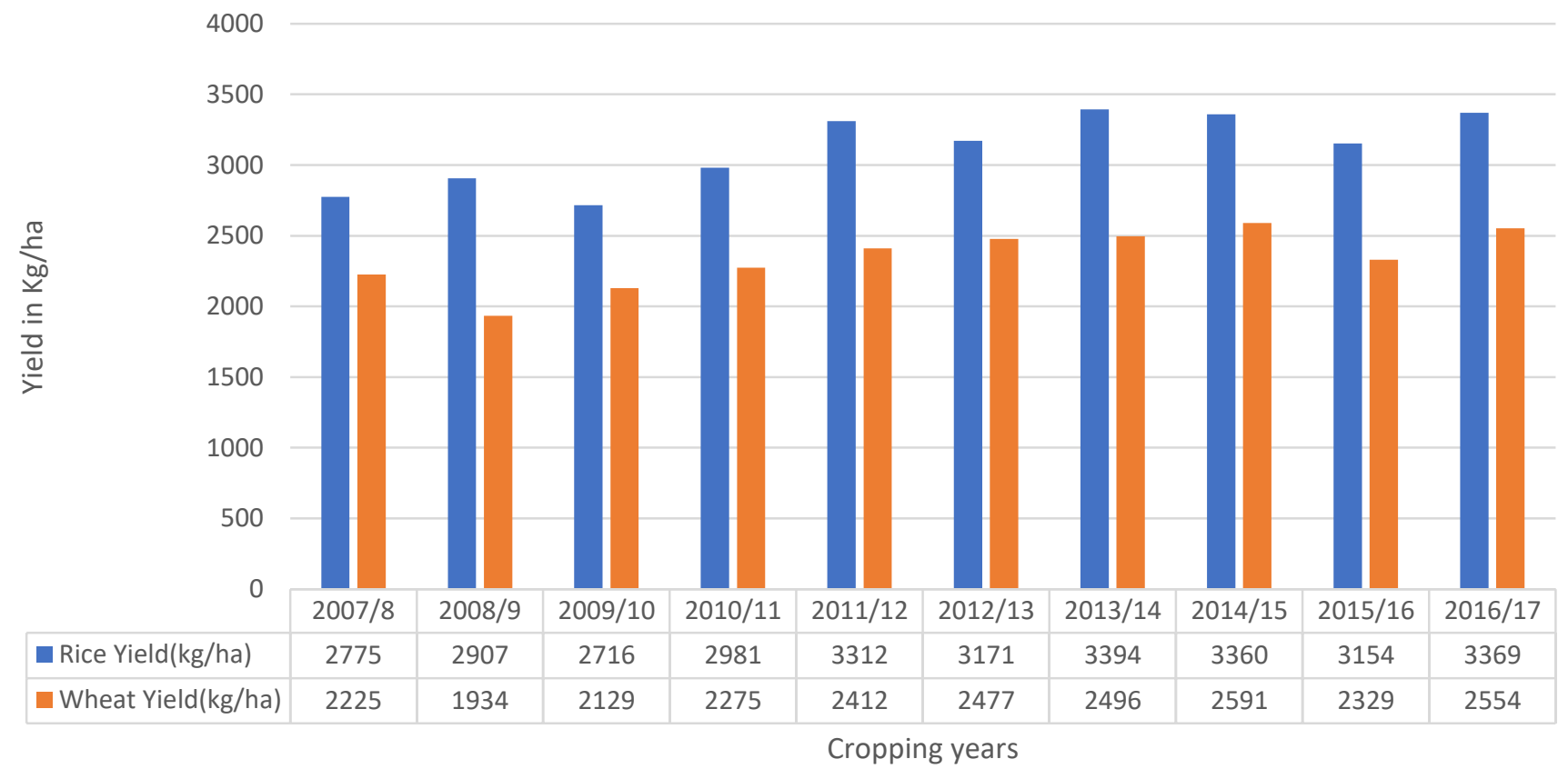

Source: MOALD 2018

Fig.1: Yield trend of rice and wheat in Nepal during 2007/8-2016/17

In recent years yield trend of rice and wheat seems to be plateauing although efforts are made to increase productivity to meet national production requirement. Incompatibility of rice and wheat varieties is also an important reason for suboptimal production of wheat. Long duration varieties of rice mature lately and provide less turnaround time for seedbed preparation in wheat, forcing farmers for late sowing of wheat. Late planted wheat and long duration varieties of wheat mostly get hit by rainfall during harvesting time ultimately damaging the production. Naturally planting of wheat is delayed in an area where soil contains excessive moisture during rice harvesting period. Oritz-Monasterio et al., (1994) observed 1\% loss in yield potential for each day the planting of wheat was delayed beyond last week of November in IGP region. Also, Ishaq et al., (2001) reported reduction of both water and nutrient use efficiencies of post ricewheat and sorghum by $38 \%$ and $22 \%$ respectively due to subsoil compaction in loamy soil. Stagnation in yield trend of major cereal crops raises question of food sufficiency in coming years for Nepal. It is necessary to enforce soil specific nutrient and water management practices to achieve stable growth rate in yield.

\subsection{Impacts of Agrochemicals on Environment and Groundwater Pollution}

Excessive application of synthetic fertilizers and other agrochemicals in rice-wheat system deteriorates the groundwater quality through runoff and leaching of chemical residues to groundwater (Karkaliya et al., 2018). This leaching and runoff process make groundwater nitrate-rich. Extracting of such polluted groundwater for human consumption and agricultural application ultimately possess a threat to crop health as well as human and livestock (Bhatt $e t$ al., 2016). Leaching of agrochemicals to groundwater aquifers can be serious in sandy soil. A study done by Pandey et al., (2017) showed that consumption of chemical fertilizerincreased at the rate of 882.43 metric tons per year from 1991/91 to 2015/16 in Nepal and it was 42828 metric tons in 2016.

Rate of consumption of agrochemicals is significantly lower in Nepal compared to neighbouring countries. Application of synthetic fertilizersincreased at the rate of $0.7791 \mathrm{~kg} / \mathrm{ha}$ per year from year 1994/95 to 2015/16 and average fertilizerconsumption in year 2015/16 was found to be 83.8 $\mathrm{kg} / \mathrm{ha}$ across the country (Pandey et al., 2017). Diwakar et al., (2008) reported that pesticide consumption in Nepal is 
increasing by about $10-20 \%$ every year. Pesticide consumption in Nepal was only $142 \mathrm{gm} / \mathrm{ha}$ in 1995 which rapidly grew to $396 \mathrm{gm} / \mathrm{ha}$ in 2014 (Adhikari 2018). With these rates, threat to groundwater pollution in Nepal is lower compared to neighbouring countries like India and China where rates are significantly higher.

\subsection{Yield Gap in Production}

The yield of rice is lowest in Nepal compared to other South Asian countries. The differences in average potential yield and actual farm-level yield is high even for improved and hybrid varieties. The gap between potential yield and actual yield at farm level is $54 \%$ per unit of land for rice varieties (CDD 2015). This yield gap is associated with technological constraints, climate change, poor soil health, unscientific methodologies and resource unavailability. The technology involved in cultivation at farmer's field lags largely compared to technology at research stations. The package of practices involved at farmers field and research station have significant differences. This is more pronounced in hills and high hills where yield gap of rice varieties ranges to $107 \%$ and $158 \%$ respectively (CDD 2015).

\subsection{Impacts of Longterm RWCS on Soil Health and Fertility}

Soil fertility, soil organic matter content (OMC), its structure and its physicochemical properties are key players of sustainable RWCS. Soil undergoes major physical, chemical and biological changes throughout every cycle of rice-wheat cropping. The fertility status of Nepalese soil is declining due to poor OMC in more than $60 \%$ of the cultivated field and haphazard use of chemical fertilizers (Khanal et al., 2012). Since the crop residues are used as fodder for cattle, residue recycling is poor in Nepal. This is one of major causes of declining soil OMC. Puddling of soil maybe crucial for water holding, weed growth suppression, reducing percolation losses and easy mechanical as well as manual transplantation of rice. But it is associated with many longterm changes in soil structure and physicochemical properties. Puddling done for reducing percolation loss also deteriorates soil physical properties by breaking down soil aggregates to form hardpans at shallow depth which leads to increased bulk density and decreases hydraulic conductivity in following wheat crop. Kukal and Aggarwal, (2003) reported that the puddling at normal depth of $10-12 \mathrm{~cm}$ develops sub-surface compaction layer at $14-20 \mathrm{~cm}$ which persists even during post-rice wheat seedbed preparation. Yield reduction of 8-9\% was found in wheat following puddled rice when compared with wheat yield following non-puddled direct-seeded rice (DSR) (Zhou et al., 2014).
Waterlogging in such soil can result in oxygen stress, diminish redox potential and enhance accumulation of phytotoxins in the root zone, ultimately decreasing wheat yield (Ladha et al., 2003). The subsurface pan creates moisture stress to lower root zone and even restricts root growth of wheat. Upon tillage after rice harvesting, medium to larger clods are formed with higher surface exposure permitting greater evapotranspiration from soil. Such tilth results in poor seed germination and seedling emergence of wheat (Chenkual and Acharya, 1990). Intensively tillage system that we currently practice is prone to loss of organic and inorganic soil nutrients through erosion and leaching. More extensive research is required to develop tillage system that would produce synergistic impacts on yield of both crop and aid in sustainable intensification of RWCS.

\subsection{Greenhouse Gas Emission Status of Nepalese RWCS}

Irrigated rice supports the accumulation of relatively higher amount of soil organic matter in rice-wheat system as compared to non-irrigated or upland condition. Water stagnated condition in rice prevents aerobic decomposition of soil organic matter $(\mathrm{SOM})$. Therefore, $\mathrm{CH}_{4}$ is produced through anaerobic decomposition of SOM from rice field. $\mathrm{CH}_{4}$ emission in Indo-Gangetic plains normally didn't exceed $30 \mathrm{~kg} / \mathrm{ha} \mathrm{CH}_{4}$ under mineral fertilization and $50 \mathrm{~kg} / \mathrm{ha} \mathrm{CH}_{4}$ under organic, which is very low compared to Central China where $\mathrm{CH}_{4}$ emission ranges from $200-900 \mathrm{~kg} / \mathrm{ha}$ under mineral fertilization and up to $1100 \mathrm{~kg} / \mathrm{ha}$ under organic system (Wassmann et al., 2004). Average maximum $\mathrm{CH}_{4}$ emission from rice field was found to be $28 \mathrm{~kg} / \mathrm{ha} / \mathrm{season}$ under rainfed condition from studies conducted at Nepal Agricultural Research Council (NARC), Khumaltar, Nepal (Malla, 2009). The same study showed $\mathrm{CH}_{4}$ emission of $49.03 \mathrm{~kg} / \mathrm{ha} / \mathrm{season}$ from rice field supplied with $50 \%$ nitrogen $+15 \mathrm{~cm}$ stubble whereas minimum $\mathrm{CH}_{4}$ emission in control plot was only $7.7 \mathrm{~kg} / \mathrm{ha}$. As for wheat crop it acts as sink for $\mathrm{CH}_{4}$ and the major greenhouse gas is $\mathrm{N}_{2} \mathrm{O}$. during wheat crop season, biological nitrogen fixation is reduced and mineralization of soil organic matter is facilitated, this accelerates the loss of SOM. $\mathrm{N}_{2} \mathrm{O}$ emission is high during dry soil state (wheat) than during water stagnated (rice) condition. This alteration of wetting and drying cycle in RWCS promotes $\mathrm{N}_{2} \mathrm{O}$ emission.

According to World Resource Institute Climate Analysis Indicator Tool, emission from agriculture increased by $38 \%$ between 1990 to 2014, for which livestock sector was the largest contributor and rice cultivation was second one (USAID, 2014). The report also stated that agriculture sector was responsible for half $(50.1 \%)$ of total emissions of Nepal 
in 2014. Synthetic fertilizers though represent small fraction (3\%) of total emission from agriculture, but its share is increasing rapidly. As of 2014, Nepal's total $\mathrm{CO}_{2}$ emission is 44.06 million metric tons which is $0.09 \%$ of world total (USAID, 2014). There is no question that emission from Nepalese RWCS is not worth considering when compared to Indian and Chinese emission, but when it comes to potential impacts of global warming and climate change in agriculture, Nepal is on top of list.

\subsection{Diverse Weed Flora}

Excessive and uncontrolled weed pressure is an important factor for the yield gap in rice-wheat system. Higher weed density in rice-wheat system signifies intense competition for nutrient, light, water and even space for growth. Since both rice and wheat are cultivated intensively, overall decrease in productivity is significant. The dominance of weed is more experienced in dry seeded rice and zero tillage plots compared to puddled rice. Since the soil is supplied with enough water, micronutrients and fertilizers, it isn't easy to suppress the weeds. Manandhar et al., (2007) reported reduction in straw yield by $13-38 \%$ and grain yield by 25 $47 \%$ compared to weed-free control plots in experiment done at paddy field in Kirtipur, Kathmandu. Yield losses in wheat due to weed was estimated to be around $10-50 \%$ in various agroecological zones of Nepal (Ranjit et al., 2009). There have been cases of persistence of Phalaris minor against isoproturon and 2,4-D. Phalaris minor is most hazardous weed for wheat in Nepal. In our current crop management system, weed seeds get mixed with harvested crop seed. So, there is long-term chance of existing hazardous weeds like $P$. minor unless we change our crop management practices.

\subsection{A threatto Biodiversity Loss}

Biodiversity loss is a critical environmental issue in most of the rice-growing countries in recent years. Since the practice of intensive industrial farming is increasing widely in many countries, the number of cultivated species is decreasing. Creating megafarms in vast area of land with purpose of cultivating only single or double crop can create serious biodiversity issues in local agroecosystem. The consequence of such farming system can range from imbalanced agroecosystem to species loss. The focus on major crops which have high market demand is reason behind decrease in number of cultivated species of crops. But this may also be closely associated with livelihood and socio-cultural aspect of farmers. In countries where farming is rice-based this issue is even more serious.

The productivity of cereal crops including (rice and wheat) is lowest in Nepal compared to other south Asian countries. To meet the nutrition requirement of ever-growing population it has become necessity to produce more from the limited cultivable lands. Accordingly, new high yielding, hybrid varieties were introduced in the country. Revolution of improved and hybrid varieties of rice and other major cereals pose threat to indigenous varieties. Before green revolution over 2500 landraces of rice were grown in Nepal but as of 2014 only 270 rice varieties are grown in different agroecological zones of which 157 are local, 59 are improved and 54 are hybrid varieties (CDD 2015). In terms of area local varieties cover only $10.2 \%$ of area whereas improved and hybrid varieties cover $82.4 \%$ and $7.4 \%$ respectively (CDD 2015). Though yield maybe high with new varieties, they are highly susceptible to diseases and pest outbreak. Also, indigenous varieties which were more tolerant to biotic and abiotic stress and belonged to local agroecosystem are now on the verge of extinction.

\subsection{Depletion of Groundwater}

Rice is a heavy consumer of water. Rice-wheat cropping system requires about $11,650 \mathrm{~m}^{3} / \mathrm{ha}$ of water, out of which major portion $7650 \mathrm{~m}^{3} / \mathrm{ha}$ goes for flooded rice (Bhatt et.al., 2016). To produce $1 \mathrm{~kg}$ of rice under irrigated condition, it requires around 5000 litres of water. Underground water has been a dependable source of irrigation all-round the year for intensive rice-wheat cultivation in South Asia. But the situation seems likely to be different under long-term scenario. Extraction of groundwater for agricultural as well as non-agricultural operations has increased sharply in IndoGangetic Plain (IGP). The per capita water availability of Nepal was $21,623 \mathrm{~m}^{3}$ in 1950 which is projected to be 4,820 $\mathrm{m}^{3}$ by 2020 (Bhatt et al., 2016). According to Tiwari et al., (2009) anthropogenic groundwater loss rate for the Ganga basin (India-Nepal) is highest $\left(\sim 22.56 \pm 3.8 \mathrm{~km}^{3}\right.$ per year) which is about $42 \%$ of total use in the region. Nepal's contribution to this huge depletion is obviously minor compared to India. There is no exact data for extraction of groundwater for agricultural and non-agricultural operations all round Nepal but the rate of extraction is increasing rapidly. This doesn't necessarily mean that reliability of underground water for irrigation in the near future should be doubted but it certainly means that the time has come for us to keep check and balance of ingoing and outgoing water from the ground. Consequences of groundwater depletion like drying of natural springs, watersheds and aquifers can be observed in Kathmandu valley as well as some districts of Terai region where groundwater has been extracted extensively. Environmental impacts will be harsh if future of intensively irrigated RWCS of South Asia relies largely upon 
underground water under current rate of groundwater recharge. Judicious water management is key to sustainability of rice-wheat system.

\subsection{Outbreak of Pest and Diseases}

The entire rice-wheat system is cultivated under high input environment. This system requires sufficient irrigations, agrochemicals (fertilizers and pesticides), micronutrient and organic inputs. This nutrient-rich environment acts as a catalyst for the growth of phytopathogens and insect-pest. The infestation of disease and insect pest adds unnecessary burden on cost of production, raising question about the sustainability of system. With excessive use of insecticides and other pesticides, insect-pest and disease are found to be resistant with current pesticides. New breeds of insect-pest are also found in many cases. This adds further challenge on sustainability of rice-wheat system. Higher dose of nitrogenous fertilizers aimed for increasing yield also promotes disease and insects in wheat.

\subsection{Socioeconomic and Livelihood Factors}

Nepalese farmers don't seem to be happy with the economic benefit of rice-wheat cultivation. The cost of production for per $\mathrm{kg}$ rice is increasing every year but farmers don't seem to be benefited from that. There is huge population of working age group who don't seem to be satisfied with agriculture profession and are shifting towards other occupations. In recent years there have been cases of large cultivable land being left uncultivated in many hilly villages due to lack of working population. The working-age group which used to provide labour force to agriculture are now leaving country for other jobs which could satisfy their economic needs. Also, farmers are shifting from cereal crops to vegetables, fruit and livestock where economic benefit is higher.

\section{AMELIORATING RICE-WHEAT CROPPING IN NEPAL}

\subsection{Conservation Agriculture}

According to Food and Agriculture Organization (FAO), CA is a farming system that promotes maintenance of permanent soil cover, minimum soil disturbances (zero tillage) and diversification of plant species. It is aimed at enhancing biodiversity and natural biological cycles in and out of the soil to improve water and nutrient use efficiency. The main motto of CA is sustainable food production. It relies on three main principles viz. minimum mechanical soil disturbances, permanent soil organic cover and species diversification. Intensive RWCS of Nepal which currently seems to be losing its sustainability can be brought on track by application of CA principles. Concept of CA differs widely from our current RWCS (especially puddled rice), but even partial application can bring positive changes. Although the initial yields might not compete with conventional method, the long-term benefits to soil health and entire agroecosystem are vital for our food security. CA is equally relevant in adapting Nepalese agriculture to climate change by establishing resiliency in the system. Intensification of rice-wheat system in sustainable manner is possible only if our agroecosystem remains functional and resilient. So, it is essential to put principles of CA into action for our long-term food security. The yield of rice maybe low under conservation agriculture but wheat yield is found to be significantly higher compared to conventional system. A four-year experiment done by Jat et al., (2019) showed that under full CA-based basmati ricewheat system, system productivity was higher by $36 \%$ and net returns by $43 \%$ compared to conventional.

\subsubsection{Zero Tillage}

Method of tillage is an important factor for determining oxygen fluxes in upper soil layer, which provides oxygen for aerobic decay of soil organic matter. In conventional system rice is transplanted in wet tillage (puddled) soil whereas following wheat crop is sown in dry tillage. Intensive tillage system in rice has been found to be detrimental to soil health and results in long term structural changes in soil. Sustainability of RWCS can't be ensured unless we modify our tillage system. Zero tillage supports minimum soil disturbances, prevents structural destruction and promotes water stable aggregates. In contrast to puddling it decreases bulk density and water penetration resistance (Zhou et al., 2014).

Under zero tillage system seeds are directly placed to required depth and spacing using zero-till seed cum fertilizer drill or other heavy seeders depending upon presence or absence of crop residue in plots. Irrigation in zero tillage direct-seeded rice (ZTDSR) is based on soil matric potential, crop growth stage and soil properties. Jat et al., (2019) reported 33\% lower water use in fully CA applied plots of rice-wheat system compared to conventional. Flooding of rice as done in conventional system is avoided here. Moving from conventional to no-tillage system may bring positive changes in soil properties, micro fauna, microflora and weed flora ultimately affecting long term crop productivity and input use efficiency but further broad study is required for making the technology equally effective to rice also.

\subsubsection{Species Diversity (Alternative Crop Rotation)}

Zero tillage in RWCS promotes early planting of wheat, which creates opportunity to integrate legume crops or other green manure crop into the system, ultimately it maximizes 
system productivity and stabilizes soil health. Variation in cropping pattern in every cropping season changes the rhizosphere affected soil area by replenishing the depleted nutrients. Replacing rice with legume or other less hungry crop for a season can increase the sustainability of system either by fixing nutrients or by providing time for replenishment of depleted nutrients. Rice and wheat both crops are good hosts of nematodes whereas legume crops are resistant, therefore integrating legumes crops (cowpea, mungbean) during intervening period increases yield of both crops significantly compared to simultaneously rice-wheat. Furthermore Bradyrhizobium sp. and Herbaspirillum sp. are found to colonize the rice roots when grown in rotation with the legume, promoting rice growth and availability of plant nutrients especially nitrogen and phosphorous (Zhou et al., 2014).

\subsubsection{Soil Organic Cover and Residue Recycling}

Organic soil cover is effective in regulating soil temperature, building healthy microbial ecology, reducing weed dominance and conserving moisture by reducing evapotranspiration. Under conventional agriculture entire crop residue is left in the field so that soil organic carbon and other nutrients can be recycled. Jat et al., (2019) reported significant increase in soil organic content by $21 \%$ in zero tillage plots with residue recycling compared to conventional.

In rice-wheat system both crops heavily consume organic and inorganic nutrients of soil to produce biomass of crop with its residue. Practicing a cropping pattern with such heavy consumer crops for subsequent cropping season causes huge depletion in the organic and inorganic nutrient pool in soil. Unlike many Indian states where paddy straw is burned in field, Nepalese farmers neither burn paddy straw nor leave in field for decay. Instead it is used as fodder for cow and buffalo all over the country. Wheat straw is also used as fodder in many districts of Terai and hilly region although nutritional value of both is very low. So Nepalese rice-wheat system is in risk of depletion of organic and inorganic component of soil unless residue of corresponding biomass is replenished into soil. Applying of farmyard manure is effective way of replenishing the soil nutrient pool but at same time it is also responsible for increased $\mathrm{CH}_{4}$ emission from rice-wheat system. So, it is vital to send crop residue back into the soil to replenish the depleted elements as well as to compensate the $\mathrm{CH}_{4}$ emission from FYM through carbon sequestration. Green manure crop like Sesbania sps., legume crops etc. are also effective. But the impact of applying crop residue is found to be higher compared to green manure crops. Incorporating green manure and crop residue in addition to synthetic fertilizers can have higher carbon sequestration ranging from $10-20 \%$ higher (Wassmann et al., 2004).

\subsection{Alternate Wetting and Drying (AWD)}

AWD technique was developed by International rice research institute to cut off the water requirement for growing rice. In this system dislike conventional method of continuous flooding, cycle of draining and re-flooding is practiced depending upon crop stage and critical water requirement. Its main aim to maintain optimum water level at any stage of crop growth. Under the AWD technique, irrigation cycle begins after two weeks of transplantation. The rice field is left to dry to a point until there is optimum water for crop growth. The water content in soil is continuously monitored through level gauge (tensiometer). The field is re-flooded once the water level has gone below optimum level. AWD technique is practiced in all stages of crop growth except during flowering when field is kept flooding. A metaanalysis done by Carrijo et al., (2017) showed that using mild AWD can reduce water consumption by $23 \%$ and it was found that soil properties can affect the AWD technique performance. The experiment done by Howell et al., (2015) on dry season rice in central Terai of Nepal showed no significant difference in yield between treatment plots, although AWD plots received 57\% less water requirement than conventional plots. In similar experiment Djaman et al., (2018) observed $27.3 \%$ less water consumption with no yield loss compared to conventional. Apart from water use efficiency AWD system enhances tillering, root growth and helps cut off $\mathrm{CH}_{4}$ emission from rice field by significant amount. Therefore, crop water use efficiency of RWCS can be improved by the application of AWD if required field infrastructures are developed. Farmers irrigating their field through pump water can have more benefit since they have more governance over irrigation water.

\subsection{Climate-Smart Agriculture (CSA)}

The main objective of CSA is to establish resilience and adaptive capacity in agro ecosystem as well as increase the productivity of system in sustainable manner. CSA techniques are oriented towards reducing greenhouse gas emission as possible. In a country like Nepal which has already experienced impacts of climate change in agriculture, it is essential to adapt its agriculture to changing climatic conditions to ensure food security for generations to come. In RWCS, CSA is primarily aimed at mitigating GHG's emission and adaptation of nutrient and water management practices with climatic variability. The technologies of CSA 
ranges from simple cultural management practices and adjustments to technical operations like weather forecast based irrigation, site-specific nutrient management (SSNM), adoption of System of Rice Intensification (SRI), need-based nutrient management and AWD practices.

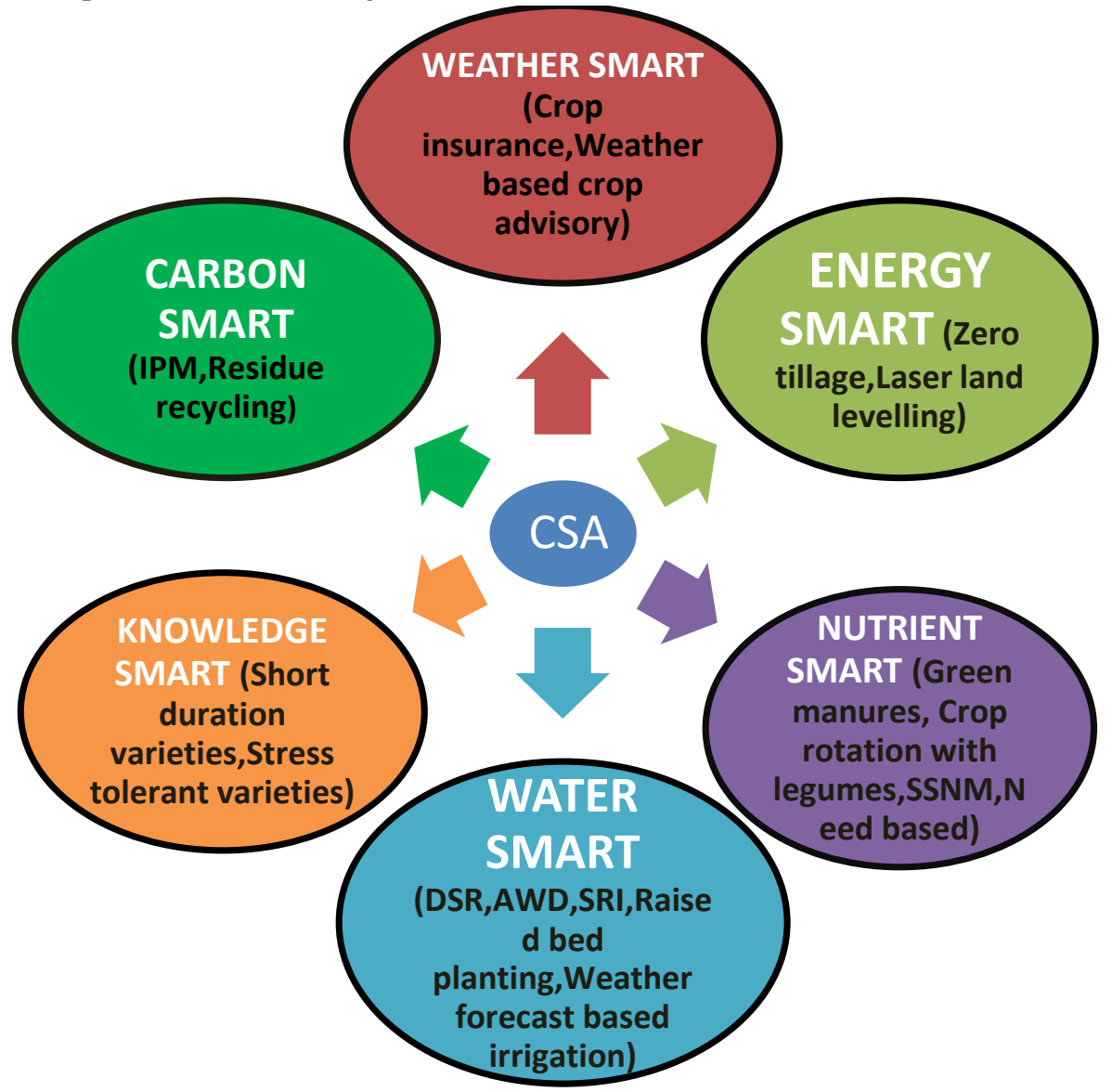

Fig.2: Climate Smart Agriculture for Sustainable Rice-Wheat System

\section{CONCLUSION}

It's no doubt that RWCS is unavoidable cropping system for food security of Nepal but with growing concerns about sustainability all around the globe, Nepal needs to think critically about environmental impacts of system on longterm. The current trend of RWCS might lead to food insecurity in near future. It is essential to adopt crop diversification practices for sustainable farming system and building resilience in agriculture. Limited research has been done in Nepal about issues concerning sustainability of the rice-wheat system. Extensive studies have to be done to conclude about various aspects and changes have to made on policies as well as farm-level practices for sustainable food security.

\section{REFERENCES}

[1] Adhikari, P. R. (2018). An overview of pesticide management in Nepal. Journal of Agriculture and Environment, 18, 95105. doi: 10.3126/aej.v18i0.19894

[2] Adhikari, V. R., Devkota, N., \& Phuyal, R. K. (2017). Impact of Climate Variation in Paddy Production in Nepal. International Journal of Economic Perspectives, 11(3), 1084-1092.

[3] Bhatt, R., Kukal, S. S., Busari, M. A., Arora, S., \& Yadav, M. (2016). Sustainability issues on rice-wheat cropping system. International Soil and Water Conservation Research, 4(1), 64-74. doi: 10.1016/j.iswcr.2015.12.001

[4] Bhujel, R. B., Jha, R. N., \& Yadav, B. (2014). An Empirical Analysis of Resource Productivity of Wheat in Eastern Tarai Region of Nepal. Nepal Agriculture Research Journal, 9, 99108. doi: 10.3126/narj.v9i0.11647

[5] Carrijo, D. R., Lundy, M. E., \& Linquist, B. A. (2017). Rice yields and water use under alternate wetting and drying 
irrigation: A meta-analysis. Field Crops Research, 203, 173180. doi: 10.1016/j.fcr.2016.12.002

[6] CDD, Crop Development Directorate, Department of Agriculture-Nepal, Rice Varietal Mapping in Nepal: Implication for Development and Adaptation, 2015,retrived from:

http://cddnepal.gov.np/downloadfile/Rice_Varietal_Mapping_ 1470895701_1512106555.pdf

[7] Chenkual, V., \& Acharya, C. L. (1990). Effect of rice-wheat and maize-wheat rotations on soil physical properties including soil water behaviour in an acidic alfisol. Journal of the Indian Society of Soil Science, 38(4), 574-582.

[8] Dhakal, S., Sedhain, G., \& Dhakal, S. (2016). Climate Change Impact and Adaptation Practices in Agriculture: A Case Study of Rautahat District, Nepal. Climate, 4(4), 63. doi: $10.3390 / \mathrm{cli} 4040063$

[9] Diwakar, J., Prasai, T., Pant, S. R., \& Jayana, B. L. (2008). Study on Major Pesticides and Fertilizers used in Nepal. Scientific World, 6(6), 76-80. doi: 10.3126/sw.v6i6.2638

[10] Djaman, K., Mel, V., Diop, L., Sow, A., El-Namaky, R., Manneh, B., ... Irmak, S. (2018). Effects of Alternate Wetting and Drying Irrigation Regime and Nitrogen Fertilizer on Yield and Nitrogen Use Efficiency of Irrigated Rice in the Sahel. Water, 10(6), 711. doi: 10.3390/w10060711

[11] Djaman, K., Mel, V., Diop, L., Sow, A., El-Namaky, R., Manneh, B., ... Irmak, S. (2018). Effects of Alternate Wetting and Drying Irrigation Regime and Nitrogen Fertilizer on Yield and Nitrogen Use Efficiency of Irrigated Rice in the Sahel. Water, 10(6), 711. doi: 10.3390/w10060711

[12] Gahatraj, S., Jha, R. K., \& Singh, O. P. (2018). Impacts of climate change on rice production and strategies for adaptation in Chitwan, Nepal. Journal of Agriculture and Natural Resources, 1(1), 114-121. doi: 10.3126/janr.v1i1.22226

[13] Gairhe, S., Shrestha, H. K., \& Timsina, K. (2018). Dynamics of Major Cereals Productivity in Nepal. Journal of Nepal Agricultural Research Council, 4, 60-71. doi: 10.3126/jnarc.v4i1.19691

[14] Greenhouse Gas Emissions Factsheet: Nepal. (2019, April 1). Retrieved from https://www.climatelinks.org/resources/greenhouse-gasemissions-factsheet-nepal.

[15] Howell, K. R., Shrestha, P., \& Dodd, I. C. (2015). Alternate wetting and drying irrigation-maintained rice yields despite half the irrigation volume, but is currently unlikely to be adopted by smallholder lowland rice farmers in Nepal. Food and Energy Security, 4(2), 144-157. doi: 10.1002/fes3.58

[16] Ishaq, M., Hassan, A., Saeed, M., Ibrahim, M., \& Lal, R. (2001). Subsoil compaction effects on crops in Punjab, Pakistan. Soil and Tillage Research,59(1-2), 57-65. doi: 10.1016/s0167-1987(00)00189-6
[17] Jat, H. S., Kumar, P., Sutaliya, J. M., Kumar, S., Choudhary, M., Singh, Y., \& Jat, M. L. (2019). Conservation agriculture based sustainable intensification of basmati rice-wheat system in North-West India. Archives of Agronomy and Soil Science, 65(10), 1370-1386. doi: 10.1080/03650340.2019.1566708

[18] Kakarliya, S. K., Kumar, S., Kakarliya, S. S., Choudhary, K. K., \& Singh, L. K. (2018). Remedial Options for Sustainability of Rice-Wheat Cropping System. Journal of Pharmacognosy and Phytochemistry, 7(2), 163-171.

[19] Kataki, P. K., Hobbs, P., \& Adhikary, B. (2001). The RiceWheat Cropping System of South Asia. Journal of Crop Production, 3(2), 1-26. doi: 10.1300/j144v03n02_01

[20] Khanal, N. P., Maharjan, K. L., \& Dongol, D. R. (2012). Soil Conservation Practices for Sustainability ofRice-wheat System in Nepal: A Review. Journal of International Development and Cooperation, 18(4), 11-20.

[21] Kukal, S. S., \& Aggarwal, G. C. (2003). Puddling depth and intensity effects in rice-wheat system on a sandy loam soil I. Development of subsurface compaction. Soil and Tillage Research, 72(1), 1-8. doi: 10.1016/s0167-1987(03)00093-x

[22] Malla, G. (2009). Climate Change and Its Impact on Nepalese Agriculture. Journal of Agriculture and Environment, 9, 6271. doi: 10.3126/aej.v9i0.2119

[23] Manandhar, S., Shrestha, B. B., \& Lekhak, H. D. (2007). Weeds of Paddy Field at Kirtipur, Kathmandu. Scientific World, 5(5), 100-106. doi: 10.3126/sw.v5i5.2665

[24] Pandey, G., Khanal, S., Pant, D., Chhetri, A., \& Basnet, S. (2017). An Overview of Fertilizer Distribution Scenario in Nepal: a Time Series Analysis (1991/922015/16). International Journal of Research in Agricultural Sciences, 4(6), 319-324.

[25] Pant, K. P. (2013). Climate Change And Food Security In Nepal. Journal of Agriculture and Environment, 13, 9-19. doi: 10.3126/aej.v13i0.7582

[26] R., J. O.-M., Dhillon, S., \& Fischer, R. (1994). Date of sowing effects on grain yield and yield components of irrigated spring wheat cultivars and relationships with radiation and temperature in Ludhiana, India. Field Crops Research, 37(3), 169-184. doi: 10.1016/0378-4290(94)90096-5

[27] Ranjit, J., Bellinder, R., Hobbs, P., Rajbhandari, N., \& Kataki, P. (2009). Mapping Phalaris minor under the Rice-Wheat Cropping System in different Agro-Ecological Regions of Nepal. Nepal Agriculture Research Journal, 7, 54-63. doi: 10.3126/narj.v7i0.1869

[28] Regmi, A. P., Ladha, J. K., Pathak, H., Pasuquin, E., Bueno, C., Dawe, D., ... Pandey, S. P. (2002). Yield and Soil Fertility Trends in a 20-Year Rice-Rice-Wheat Experiment in Nepal. Soil Science Society of America Journal, 66(3), 857. doi: 10.2136/sssaj2002.8570

[29] Gami, S. K., Ladha, J. K., Pathak, M., Shah, M. P., Pashquin, E., Pandey, S. P., Hobbs, P. R., Joshy, D., Mishra, R. (2001). Long-term changes in yield and soil fertility in a twenty-year 
rice-wheat experiment in Nepal. Biology and Fertility of Soils, 34(1), 73-78. doi: 10.1007/s003740100377

[30] Sharma, P. K., Ladha, J. K., \& Bhushan, L. (2003). Soil Physical Effects of Puddling in Rice-Wheat Cropping Systems. In Improving the Productivity and Sustainability of Rice-Wheat Systems: Issues and Impacts (pp. 97-113). 5585 Guilford Rd., Madison, WI 53711 USA: American Society of Agronomy. doi: 10.2134/asaspecpub65.c5

[31] Thapa-Parajuli, R., \& Devkota, N. (2016). Impact of Climate Change on Wheat Production in Nepal. Asian Journal of Agricultural Extension, Economics \& Sociology, 9(2), 1-14. doi: 10.9734/ajaees/2016/22555

[32] Tiwari, V. M., Wahr, J., \& Swenson, S. (2009). Dwindling groundwater resources in northern India, from satellite gravity observations. Geophysical Research Letters, 36(18). doi: 10.1029/2009gl039401

[33] Tripathi, B. P., Bhandari, H. N., \&Ladha, J. K. (2019). Rice Strategy for Nepal. Acta Scientific Agriculture, 3(2), 171180.

[34] USAID 2014, Greenhouse gas emissions in Nepal,retrived from:

https://www.climatelinks.org/sites/default/files/asset/documen t/2019_USAID_Nepal\%20GHG\%20Emissions\%20Factsheet. pdf

[35] Wassmann, R., Neue, H., Ladha, J., \& Aulakh, M. (2004). Mitigating Greenhouse Gas Emissions from Rice-Wheat Cropping Systems in Asia. Environment, Development and Sustainability, 6(1/2), 65-90. doi: 10.1023/b:envi.0000003630.54494.a7 